\title{
RICHTERITE AND ACTINOLITE FROM THE SIILINJ ̈̈RVI CARBONATITE COMPLEX, FINLAND
}

\author{
Kauko Puustinen
}

\begin{abstract}
Punstinen, Kauko 1972: Richterite and actinolite from the Siilinjärvi carbonatite complex, Finland. Bull. Geol. Soc. Finland 44, 83-86.

Chemical, optical and X-ray data are given for the richterite in the glimmerite and actinolite in the syenite of the Silinjärvi carbonatite complex.

Kauko Puustinen, Technical University, Dept. of Mining and Metallurgy, 02150

Otaniemi, Finland.
\end{abstract}

\section{Introduction}

The Siilinjärvi carbonatite complex is situated some $20 \mathrm{~km}$ to the north of the city of Kuopio, Eastern Finland, at lat. $63^{\circ} 08^{\prime} \mathrm{N}$ and long. $27^{\circ} 44^{\prime} \mathrm{E}$. It forms a roughly tabular, subvertical body, some $16 \mathrm{~km}$ long and up to $1.5 \mathrm{~km}$ wide. A detailed description of the complex has been given by Puustinen (1971).

The sequence of emplacement began with the intrusion of the ultramafic phase (glimmerite), followed by the intrusion of syenite. The carbonatite proper (sövite) was intruded into the glimmeritic rocks.

Glimmerite is a quartz-and feldspar-free rock which consists of phlogopite, alkali amphibole, apatite and some calcite. It is medium grained with color varying from red-brown to black. The phlogopite is sometimes reddish-brown and shows an anomalous reverse pleochroism (tetraferriphlogopite). Zircon is often found as an accessory mineral in connection with the amphibole-rich types of glimmerite.

Syenite consists mainly of microcline, amphibole and pyroxene. Albite, quartz and biotite are found as accessories.

Carbonatite proper forms mixed rocks together with the glimmerite, the amount of amphibole in the carbonatite being, however, neglible.

\section{Occurrence}

Amphibole is very common in the glimmerite. Locally its amount may be up to $50 \%$ by volume but usually is less than $15 \%$. It represents a primary crystallization and does not show any sign of alterations.

In hand specimens the amphibole occurs in many cases as euhedral crystals which measure up to $20 \mathrm{~cm}$. The color is usually dark green. 
Mineralogical data for the alkali amphibole of glimmerite shows that it is related to richterite.

The amphibole from syenite is actinolite. The total amount of amphibole and pyroxene in syenite is usually less than $25 \%$ by volume. The pyroxene is an aegirine-augite.

To the naked eye the differences between the Siilinjärvi actinolite and richterite are very small and therefore the nature of an amphibole is determined only by detailed studies.

\section{X-ray crystallography}

The unit cell dimensions (Table 1) were determined from zero-level Buerger precission photographs using MoK $\alpha$-radiation (Nos 1 and 3) and from Weissenberg photographs using $\mathrm{CuK} \alpha$ -radiation (No 2). The $\beta$-angle of No 2 was measured from a precession photograph. The films were calibrated with the reflections of an oriented silicon crystal. The accuracy obtained corresponds to probable errors of \pm 0.010 , $\pm 0.020, \pm 0.005 \AA$ and $0^{\circ} 05^{\prime}$ for $\mathrm{a}_{0}, \mathrm{~b}_{0}, \mathrm{c}_{0}$ and $\beta$ respectively.

\section{TABLE 1}

Physical properties and unit cell dimensions of richterite from glimmerite and actinolite from syenite, Siilinjärvi carbonatite complex

\begin{tabular}{|c|c|c|c|}
\hline & 1. & 2. & 3. \\
\hline$\alpha \ldots \ldots \ldots \ldots \ldots \ldots$ & 1.624 & 1.618 & 1.622 \\
\hline$\beta \ldots \ldots \ldots \ldots \ldots$ & 1.642 & 1.630 & 1.638 \\
\hline$\gamma \ldots \ldots \ldots \ldots \ldots \ldots$ & 1.650 & 1. 640 & 1.646 \\
\hline$\gamma-a \ldots \ldots \ldots \ldots \ldots$ & 0.024 & 0.022 & 0.024 \\
\hline $2 \mathrm{~V} \alpha \ldots \ldots \ldots \ldots$ & $65^{\circ}$ & $64^{\circ}$ & $74^{\circ}$ \\
\hline $\mathrm{c} \wedge \gamma \ldots \ldots \ldots \ldots$ & $35^{\circ}$ & $24^{\circ}$ & $14^{\circ}$ \\
\hline $\mathrm{x} \ldots \ldots \ldots \ldots$ & v.p.gr. & cls. & v.p.gr. \\
\hline$Y \ldots$ & p.gr. & v.p.gr. & p.gr. \\
\hline$Z \ldots \ldots \ldots$ & bl.gr. & p.gr. & ol.gr. \\
\hline$D(g / c c) \ldots \ldots \ldots$ & 3.082 & 3.058 & 3.084 \\
\hline$a_{0}(\AA) \ldots \ldots \ldots \ldots$ & 9.790 & 9.906 & 9.879 \\
\hline$b_{0} \ldots \ldots \ldots \ldots$ & 17.959 & 18.007 & 18.091 \\
\hline$c_{0} \ldots \ldots \ldots \ldots$ & 5.291 & 5.279 & 5.290 \\
\hline$\beta \ldots \ldots \ldots \ldots$ & $104^{\circ} 35^{\prime}$ & $104^{\circ} 24^{\prime}$ & $104^{\circ} 38^{\prime}$ \\
\hline$a_{0} \sin \beta(\AA) \ldots \ldots \ldots$ & 9.475 & 9.595 & 9.559 \\
\hline $\mathrm{V}\left(\AA^{3}\right) \ldots \ldots \ldots \ldots$ & 900.3 & 912.1 & 914.8 \\
\hline
\end{tabular}

v. = very, p. = pale, gr. = green, bl. = blue, cls. $=$ colorless and ol. $=$ olive.

1. Richterite, Lake Saarinen. (R86-33.40)

2. Richterite, Lake Särkilampi. (87-1/KP-67)

3. Actinolite, east of Lake Särkilampi. (55-9/KP-67)
The X-ray data for the Siilinjärvi amphiboles are in agreement with the values given for synthetic minerals ( $c f$. Kohn and Comeforo, 1955; Huebner and Papike, 1970).

\section{Chemical composition}

Table 2 gives the chemical composition of the Siilinjärvi amphiboles. The atomic ratios have been calculated on the basis of 23 oxygen atoms per unit cell, thus eliminating the possible amounts of $\mathrm{F}$ and $\mathrm{Cl}$ in the mineral ( $c f$. Simonen and Vorma, 1969).

According to Leake (1968) richterite is defined as a $\mathrm{Ca}$ - and $\mathrm{Al}$-poor, $\mathrm{Na}$ - and $\mathrm{Si}$-rich amphibole of theoretical composition $\mathrm{Na}_{2} \mathrm{CaMg}_{5} \mathrm{Si}_{8} \mathrm{O}_{22}$ $(\mathrm{OH})_{2}$; consequently the name richterite may be used only when $\mathrm{Si}>7.25, \mathrm{Ca}+\mathrm{Na}+\mathrm{K}>2.50$, $\mathrm{Ca}<1.50$ and $\mathrm{Na}>1.00$. The values for the Siilinjärvi richterite are comparable with these values.

In addition to $\mathrm{Na}$ richterite also contains some K. A complete solid solution series between sodic richterite $\mathrm{NaNaCaMg} \mathrm{Si}_{8} \mathrm{O}_{22}(\mathrm{OH})_{2}$ and potassic richterite $\mathrm{KNaCaMg} \mathrm{Si}_{8} \mathrm{O}_{22}(\mathrm{OH})_{2}$ can be synthesized (Huebner and Papike, 1970). The relatively high content of $\mathrm{K}$ in the Siilinjärvi richterite is also in accordance with the presence of great amounts of phlogopite in the ultramafic intrusion phase of the complex.

In the Y-type cations of richterite a substitution of $\mathrm{Mg}$ by $\mathrm{Fe}^{2+}$ exists giving rise to ferrorichterite with up to $27.27 \%$ FeO (Chapman and Williams, 1935). The replacement of $\mathrm{Mg}$ by $\mathrm{Fe}^{3}+$ is also common, the mineral in general having a high $\mathrm{Fe}^{3}+: \mathrm{Fe}^{2+}$ ratio (Deer et al., 1965, p. 353); an extreme example is ferririchterite (Bilgrami, 1955) with $18.44 \% \mathrm{Fe}_{2} \mathrm{O}_{3}$. Manganous richterite, up to $8.69 \% \mathrm{MnO}$, has been found associated with manganese minerals (Sundius, 1946).

The Siilinjärvi actinolite from syenite contains more $\mathrm{Na}$ and $\mathrm{K}$ than the analyses given in the literature ( $c f$. Deer et al., 1965, p. 251-253). In some tremolites moderate amounts of $\mathrm{Na}$ are 
TABLE 2

Chemical analyses ( $\mathrm{Wt} \%$ ) and atomic ratios bised on 23 oxygen atoms per unit cell of richterite from glimmerite and actinolite from syenite, Siilinjärvi carbonatite complex. Analyses by P. Ojanperä

\begin{tabular}{|c|c|c|c|}
\hline & 1. & 2. & 3. \\
\hline $\mathrm{SiO}_{2} \ldots \ldots \ldots \ldots \ldots$ & 53.43 & 56.03 & 55.04 \\
\hline $\mathrm{TiO}_{2} \ldots \ldots \ldots \ldots$ & 0.14 & 0.10 & 0.19 \\
\hline $\mathrm{Al}_{2} \mathrm{O}_{3} \quad \ldots \ldots \ldots \ldots$ & 2.13 & 0.78 & 1. 50 \\
\hline $\mathrm{Fe}_{2} \mathrm{O}_{3} \quad \ldots \ldots \ldots \ldots$ & 7.78 & 5.68 & 4.06 \\
\hline $\mathrm{FeO} \ldots \ldots \ldots \ldots$ & 3.12 & 1.58 & 6.04 \\
\hline $\mathrm{MnO} \ldots \ldots \ldots \ldots$ & 0.11 & 0.07 & 0.31 \\
\hline $\mathrm{MgO} \ldots \ldots \ldots \ldots$ & 16.95 & 20.19 & 17.29 \\
\hline $\mathrm{CaO} \ldots \ldots \ldots \ldots$ & 6.57 & 5.89 & 11.18 \\
\hline $\mathrm{Na}_{2} \mathrm{O} \ldots \ldots \ldots \ldots$ & 5.07 & 4.87 & 1.56 \\
\hline $\mathrm{K}_{2} \mathrm{O} \ldots \ldots \ldots \ldots$ & 1.58 & 2.62 & 0.68 \\
\hline $\mathrm{P}_{2} \mathrm{O}_{5} \ldots \ldots \ldots \ldots$ & 0.10 & 0.06 & 0.05 \\
\hline $\mathrm{CO}_{2}{ }^{\circ} \ldots \ldots \ldots \ldots$ & 0.72 & - & - \\
\hline $\mathrm{H}_{2} \mathrm{O}^{+} \ldots \ldots \ldots \ldots \ldots$ & 1.92 & 1.71 & 1.67 \\
\hline \multirow[t]{2}{*}{$\mathrm{H}_{2} \mathrm{O}^{-} \ldots \ldots \ldots \ldots$} & 0.04 & 0.05 & 0.03 \\
\hline & 99.66 & 99.63 & 99.60 \\
\hline
\end{tabular}

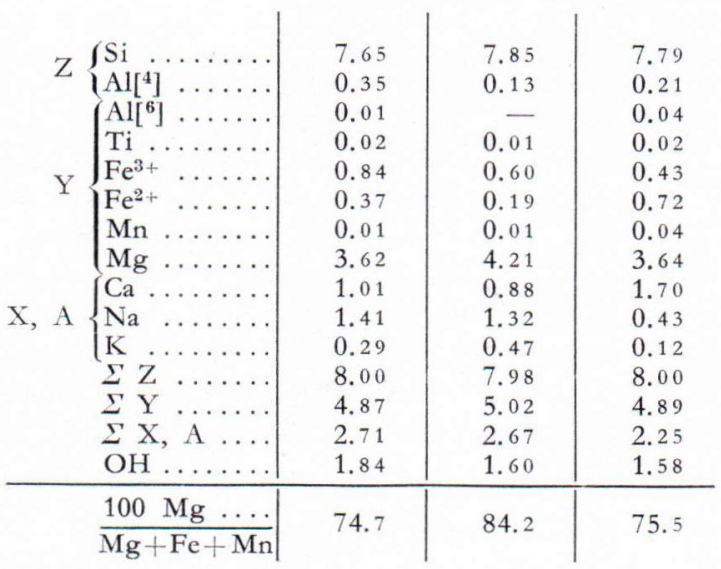

1. Richterite, Lake Saarinen. (R86-33.40)

2. Richterite, Lake Särkilampi. (87-1/KP-67)

3. Actinolite, east of Lake Särkilampi. (55-9/KP-67)

present and it is possible that there is a chemical series between tremolite and richterite (Sundius, 1946). The richterite formulae may namely be regarded as derived from tremolite by the substitution of $\mathrm{Na}$ for $\mathrm{Ca}$ in $\mathrm{X}$ accompanied by the addition of $\mathrm{Na}$ in the $\mathrm{A}$-site.

\section{Optical and physical properties}

The optical and physical properties of the Siilinjärvi amphiboles are given in Table 1.
Pleochroism is usually very weak, bluish tints are, however, sometimes observed. The minerals, especially richterite, exhibit abnormal interference colors due to the strong dispersion of the bisectries. The weak pleochroism colors and the relatively low refractive indices of richterite may be essential for the optical identification of the mineral from other alkali amphiboles.

\section{Discussion}

Richterite occurs in various geologic environments such as in metamorphosed limestones (Sundius, 1946), potassic lavas (Carmichael, 1967), kimberlites (Erlank and Finger, 1970) and in carbonatites.

A wide variety of amphiboles has been reported in carbonatite complexes, ranging from ordinary hornblende and tremolite through somewhat sodic amphiboles to strongly alkaline types such as riebeckite (Heinrich, 1966). In East Africa richterite appears to be confined to calcite-rich rocks such as carbonatites, and has not been observed in fenites (Sutherland, 1969). In Lesnaya Varaka, Kola Peninsula, it is found in dolomite-amphibole rocks (Kukharenko et al., 1965). The richterite from the carbonatites at Iron Hill, Colorado, has been described by Larsen (1942), who, like Miyashiro (1957), has used the name soda tremolite instead of richterite.

The occurrence of richterite in the glimmerite of the Siilinjärvi complex is in agreement with the general chemical character of the rocks. The presence of sufficient quantites of $\mathrm{Na}$ and $\mathrm{Fe}$ would have given rise to alkali amphiboles such as riebeckite and arfvedsonite, as is generally the case in carbonatite complexes. This also matches the statement of Ernst (1968) that richterite is evidently restricted to high temperature environments and to rock bulk compositions rich in both $\mathrm{Na}$ and $\mathrm{Ca}$ relative to $\mathrm{Al}$.

\section{Author's note}

After this manuscript was submitted to press, an error was discovered in the $\mathrm{K}$-Ar age deter- 
minations of the Siilinjärvi minerals ( $c f$. Puustinen, 1971, p. 38). The computer calculations showed too large argon contents. The corrected values are as follows:

\begin{tabular}{cccc}
$\begin{array}{c}\text { Mineral } \\
\text { Phlogopite }\end{array}$ & $\ldots$ & Age (m. y.) & \multicolumn{1}{c}{ Ref. No. } \\
$»$ & $\ldots$ & $1785 \pm 30$ & $204-2 / \mathrm{KP}-69$ \\
$»$ & $\ldots$ & $1790 \pm 30$ & $45-1 / \mathrm{KP}-67$ \\
$»$ & $\ldots$ & $1985 \pm 30$ & $71-6 / \mathrm{KP}-67$ \\
Richterite & $\ldots$ & $2530 \pm 45$ & $71-5 / \mathrm{KP}-67$ \\
Actinolite & $\ldots$ & $2260 \pm 42$ & $55-9 / \mathrm{KP}-67$
\end{tabular}

Acknowledgements - Dr. Atso Vorma, Geological Survey of Finland, gave the author valuable aid in the $\mathrm{X}$-ray determinations and he also critically read the manuscript. Chemical analyses were made by Mr. P. Ojanperä, M. A., Geological Survey of Finland. Mr. John Nelson, M. Met., Technical University, Otaniemi, checked the language of the English manuscript.

\section{REFERENCES}

Bilgrami, S. A. (1955) Manganese amphiboles from Chikla, Bhandara district, India. Min. Mag. 30, pp. 633-644.

Carmichael, Ian S. E. (1967) The mineralogy and petrology of the volcanic rocks from the Leucite Hills, Wyoming. Contr. Mineral. and Petrol. 15, pp. 24-66.

Chapman, Randolph W. and Williams, Charles R. (1935) Evolution of the White Mountain magma series. Am. Mineralogist 20, pp. 502-530.

Deer, W. A., Howie, R. A. and Zussman, J. (1965) Rock-forming minerals, Vol. 2, Chain silicates. Longmans, London.

Erlank, A. J. and Finger, L. W. (1970) The occurrence of potassic richterite in a mica nodule from the Wesselton Kimberlite, South Africa. Carnegie Inst. Wash. Year Book 68, pp. 320-324.

Ernst, W. G. (1968) Amphiboles. Minerals, rocks and inorganic materials. Monograph series of theoretical and experimental studies, Vol. 1. Springer-Verlag, New York.

Heinrich, E. Wm. (1966) The geology of carbonatites. Rand McNally \& Co., Chicago.

Huebner, J. Stephen and Papike, J. J. (1970) Synthesis and crystal chemistry of sodium-potassium richterite. $(\mathrm{Na}, \mathrm{K}) \mathrm{NaCaMg}_{5} \mathrm{Si}_{8} \mathrm{O}_{22}(\mathrm{OH}, \mathrm{F})_{2}$ : a model for amphiboles. Am. Mineralogist 55, pp. 1973-1992.

Kohn, J. A. and Comeforo, J. E. (1955) Synthetic asbestos investigations, II: X-ray and other data on synthetic fluor-richterite, -edentite, and -boron edenite. Am. Mineralogist 40, pp. 410-421.

Kunharenko, A. A. et al. (1965) Caledonian complex of ultrabasic, alkalic rocks and carbonatites of the Kola Peninsula and Northern Karelia (In Russian). Izdatel'stvo NEDRA, Moscow.

Larsen, Esper S. (1942) Alkalic rocks of Iron Hill, Gunnison County, Colorado. U.S. Geol. Surv. Prof. Paper 197-A.

Leake, Bernard E. (1968) A catalog of analyzed calciferous and subcalciferous amphiboles together with their nomenclature and associated minerals. Geol. Soc. America Special Paper 98.

Miyashiro, A. (1957) Chemistry, optics and genesis of the alkali amphiboles. Journ. Fac. Sci. Univ. Tokyo, Sec. II, Vol. 11, Pt. 1, pp. 57-83.

Puustinen, Kauko (1971) Geology of the Siilinjärvi carbonatite complex, Eastern Finland. Bull. Comm. géol. Finlande 249.

Simonen, Ahti and Vorma, Atso (1969) Amphibole and biotite from rapakivi. Bull. Comm. géol. Finlande 238.

Sundius, N. (1946) The classification of the hornblendes and the solid solution relations in the amphibole group. Sveriges Geol. Unders., Ser. C, No. 480.

Sutherland, Diana S. (1969) Sodic amphiboles and pyroxenes from fenites in East Africa. Contr. Mineral. and Petrol. 24, pp. 114-135.

Manuscript received, June 10, 1971. 